\title{
STATE-OF-THE-ART REPORT ON Seismic Performance of Unreinforced MASONRY BUILdings
}

\author{
By Michel Bruneau, ${ }^{1}$ Member, ASCE
}

\begin{abstract}
A large proportion of North America's older building inventory is of unreinforced masonry (URM), constructed in the absence of mandatory earthquake design requirements, and unquestionably recognized as the type of construction most vulnerable to earthquakes. Awareness of this seismic hazard is relatively new in eastern North America. In addition, the nature of the seismic risk and other engineering constraints there shed a new and different perspective on the problem. This state-of-the-art paper on the seismic performance of URM buildings summarizes knowledge that has already gained some acceptance in parts of North America, and outlines current limitations. Concerns regarding the seismic performance of existing URM buildings are formulated in an eastern North American seismicity context. The various failure modes of URM buildings or components subjected to earthquake excitation are described, and, when possible, illustrated. The state-of-practice as required by North American building design codes and standards is summarized. A special analytical procedure of the Uniform Code for Building Conservation, largely inspired from the Agbabian, Barnes, and Kariotis (ABK) methodology for the mitigation of seismic hazards in existing buildings, is reviewed.
\end{abstract}

\section{INTRODUCTION}

The seismic hazards posed by existing unreinforced masonry (URM) buildings have long been recognized. However, this awareness is relatively new in eastern North America. Although recent damaging North American earthquakes have accelerated efforts to implement mandatory seismic-resistant design requirements throughout the eastern United States, in Canada, where such requirements have been in place for over 20 years, they have prompted some owners to fund seismic retrofitting projects, and others to seriously contemplate the possibility. Not surprisingly, old URM buildings are the prime target.

To determine if, and what level of, retrofitting is required for an existing structure, an engineering analysis must first be performed. In the absence of legislation prescribing how, or against which basis, this structural assessment is to be accomplished, engineers are free to establish both. At first, this may appear to the designer as an ideal situation. However, in eastern North America, the long return period of major earthquakes, the absence of interim perceptible seismic activity, and the often small-to-moderate predicted intensity of the maximum credible earthquakes shed a new and different perspective on the problem. For example, the real "threshold" of damage of a given URM structure may only be slightly exceeded during a short-duration magnitude 6.0 earthquake, but a conventional engineering assessment based on code procedures may be incapable of predicting this satisfactory performance, labeling the building as seismically unsafe. Fur-

${ }^{1}$ Assoc. Prof., Civ. Engrg. Dept., 161 Louis Pasteur, Univ. of Ottawa, Ottawa, Ontario K1N $6 \mathrm{~N} 5$.

Note. Discussion open until June 1, 1994. To extend the closing date one month, a written request must be filed with the ASCE Manager of Journals. The manuscript for this paper was submitted for review and possible publication on July 13, 1992. This paper is part of the Journal of Structural Engineering, Vol. 120, No. 1, January, 1994. CASCE, ISSN 0733-9445/94/0001-0230/\$1.00 + \$.15 per page. Paper No. 2440. 
thermore, owners concerned with the mitigation of seismic hazards in eastern North America, at this time, are sometimes sophisticated; some are public agencies staffed with engineers, and are quite capable of dismissing engineering evaluations lacking credibility, i.e., based on too conservative or liberal modeling and analytical assumptions. The structural engineer who operates in that context must ethically conciliate his professional responsibility and understanding of the seismic performance of URM buildings with the owner's perception of seismic safety, all while remaining competitive. In that context, the potential benefits ensuing from the development of better tools to accurately determine the true seismic resistance of URM structures can be appreciated.

Many researchers have recently investigated various aspects of the seismic performance of URM buildings, but the results of these studies remain scattered and not necessarily known or easily accessible to practicing engineers in eastern North America. Therefore, a literature review has been conducted to assess the state-of-the-art on the seismic performance of URM buildings, summarize the lessons to be learned from the reported performance, and identify the areas that require further research.

In this paper, the concerns regarding this performance of existing URM buildings, the state-of-practice as required by North American building codes and standards, and the known modes of failure of URM buildings are presented. In a future paper, the available results from experimental and analytical studies as well as research on advanced modelization of URM buildings will be reviewed. Clearly, the intent is not to present new or original work by the writer but to summarize information available in the open literature that should be of interest to practicing engineers, for the reasons previously stated, but also to researchers planning to undertake studies on this topic.

Although this paper broadly refers to existing URM buildings, it must be noted that the problems germane to special types of structures (i.e., single-story masonry houses or adobe houses) or pertaining to URM used as infill to reinforced concrete or steel frames are beyond the scope of this study.

\section{DESCRIPTION OF SEISMIC HAZARD IN EXISTING URM BUILDINGS}

\section{Issues Pertaining to URM Structures}

A large proportion of North America's older building inventory is of unreinforced masonry, constructed in the absence of mandatory earthquakedesign requirements. URM is unquestionably recognized as the type of construction most vulnerable to earthquakes. Paradoxically, many URM buildings house key infrastructure or governmental activities, and others would need to be operational in postdisaster situations.

These older buildings tend to be at greater seismic risk than comparable new buildings, not only because they have been designed to little or no seismic loading requirements, but also because they are not capable of dissipating energy through large inelastic deformations during an earthquake (i.e. nonductile). For example, it was customary, approximately 50 years ago, to simply support floors on stone or masonry corbels. This practice is no longer permitted. During earthquakes, walls vibrate laterally and try to separate from the floors; should these be only simply supported on corbels, they usually slip off their support, leading to dramatic collapses often seen after major earthquakes. Masonry walls themselves, without reinforcement, can tear apart in an explosive manner in a seismic event. 
Not surprisingly, unreinforced masonry construction all but practically disappeared from seismic regions when earthquake-resistant design requirements where implemented in seismically active regions. Reinforced masonry, as a logical extension, was instead promoted for new constructions, and research to improve and legitimize structural systems built of that material flourished. Owing to this shift in focus, little was done to improve the understanding on the ultimate cyclic behavior of unreinforced masonry construction, a construction method of the past.

However, earthquakes that occurred over the last 15 years repeatedly demonstrated that the older existing infrastructure, and URM buildings in particular, cannot be ignored. For small-to-moderate earthquakes, older structures suffered considerable damage while most newer buildings engineered to modern standards survived. For large earthquakes, URM building failures and related deaths and injuries were even more considerable.

These recent earthquakes have contributed to the advancement of earthquake awareness, and impressed the need to review the seismic adequacy of existing buildings and elaborate strengthening strategies when required. In that perspective, some investigations on the seismic performance of URM buildings were conducted. An improved understanding of their behavior ensued. This provided the basis to enact ordinances mandating the seismic rehabilitation of URM buildings in some cities exposed to the highest seismic risk.

However, the realistic assessment of the adequacy of many types of existing URM buildings remains a complex task, particularly when subjected to small and moderate earthquakes.

\section{Special Concerns to Eastern North America}

The seismic risks are particularly severe in many parts of eastern North America. Unfortunately, the generally lower level of seismic activity between major shocks instills a lack of earthquake awareness. Consequently, recommendations to review the seismic resistance of existing structures meet considerable resistance, even for key postdisaster critical structures. Owners typically fear that engineers would perform seismic-resistance adequacy evaluations based on conservative analytical assumptions, mostly disregarding the potentially favorable contribution of structural or nonstructural elements whose effects cannot be quantified. For example, century-old buildings can sometimes be found to have no or little "theoretical" resistance to wind when analyzed according to accepted modern structural engineering practice and procedures, whereas the loading history of such structures actually demonstrates otherwise.

Owners must also reconcile the potential need for expensive structural retrofitting with the levels of seismic risk and consequences of inaction. Clearly, for the mitigation of the seismic hazards to proceed effectively in regions of eastern North America of low-to-moderate seismicity, the adequacy evaluation of existing structures must be closely interrelated to the reliability and performance level expected of the targeted facilities by owners, as well as the various probabilities of earthquake occurrence. Although the protection of life may be a sufficient minimum requirement for common URM buildings, when a building also acts as a symbol of national pride, the survival of all its occupants would be little consolation for its quasitotal loss due to significant damage.

In that perspective, the prime engineering goal would be to synthesize a realistic, neither unduly conservative nor permissive, statement of the seis- 
mic resistance capacity and ductility of the structural as well as the architectural components of the buildings. Conducting all steps of the seismic adequacy evaluation using conservative engineering analysis and design assumptions will make this goal unattainable. Similarly, overestimating the actual capacity of each structural or nonstructural element to resist damaging cycles of seismic excitation could lead to a false and dangerous sense of security. The challenge lies in establishing a realistic analytical model of the system and providing the most accurate and reliable assessment of its actual capacity balancing the views obtained from the buildings' recorded performance history and the results from state-of-the-art analysis techniques.

\section{GENERAL MODES OF FAILURE OF URM BUILDINGS DURING EARTHQUAKES}

Recent earthquakes have greatly contributed in raising the awareness of the seismic hazards attributable to URM buildings. The performance of such buildings is extensively documented in published reconnaissance reports (Scholl and Stratta 1984; Shah et al. 1984; Reitherman et al. 1984; Kariotis 1984; Adham 1985; Reitherman 1985; Swan et al. 1985; Esteva 1988; Hart et al. 1988; Deppe 1988; Moore et al. 1988; Muria-Vila and Meli 1989; Meli 1989; "Armenia" 1989; Mitchell et al. 1989; "Loma" 1990; Bruneau 1990; Cross and Jones 1991; Rutherford and Chekene 1991; Kariotis et al. 1991) from which a number of observations are possible. Generally

- With the exception of a comprehensive data collection by Rutherford and Chekene (1991) and a few other reports, damage surveys reported in the literature tend to concentrate on the downtown cores where the building stock consists mostly of older URM buildings, and may thus be biased toward higher damage (Shah et al. 1984).

- In many instances when URM buildings were noticed to survive earthquakes undamaged (Hart et al. 1988; Deppe 1988; Freeman 1932), the reasons for their satisfactory performance are speculative or not well understood.

- Selected URM buildings having survived or not earthquakes, with one notable exception (Tena-Colunga 1992), have never been the subject of in-depth studies, which are regularly done for reinforced concrete or steel buildings. This could be partly attributable to the difficulty in retracing the original drawings of old buildings.

- In many instances, particularly for moderate earthquakes, structures that did not completely collapse were condemned as a result of subsequent structural evaluations.

- There is a relationship between the quality of construction/materials, peak ground accelerations (PGA) and damage; failures have been reported for PGA as low as $0.1 \mathrm{~g}$ in cases of very poor construction quality (Reitherman 1985), whereas very few monumental, institutional, or governmental high-quality URM buildings have been observed to fail, even at large PGA. However, as some large prestigious buildings have suffered severe damage (Elsesser et al. 1991), the preceding presumption of superior performance remains unquantified.

- Stone masonry buildings with thick exterior walls have also been severely damaged or collapsed when of poor construction but sur- 
vived intact major earthquakes when exhibiting excellent workmanship and a strong earthquake awareness in their architecture (DerKiureghian 1990; “Armenia” 1989).

- The potential out-of-plane failure of URM elements (parapet, veneers, gables, and unanchored walls) during earthquakes constitutes the most serious life-safety hazard for this type of construction.

Furthermore, a number of common failure modes of URM buildings have repeatedly been observed by these reconnaissance teams. The failures can be regrouped in the following categories:

- Lack of anchorage

- Anchor failure

- In-plane failures

- Out-of-plane failure

- Combined in-plane and out-of-plane effects

- Diaphragm-related failures

These failures are described in the next subsections.

\section{Lack of Anchorage}

In many URM buildings, there is a total absence of positive anchorage of the floors and roof to the URM walls. The ends of joists and beams from the gravity system rest on the walls being simply supported; sometimes, special corbels are constructed for this purpose, but most commonly the URM wall were constructed around the supported beams, either tightly filling with masonry the recessed support or, less expensively, by using a

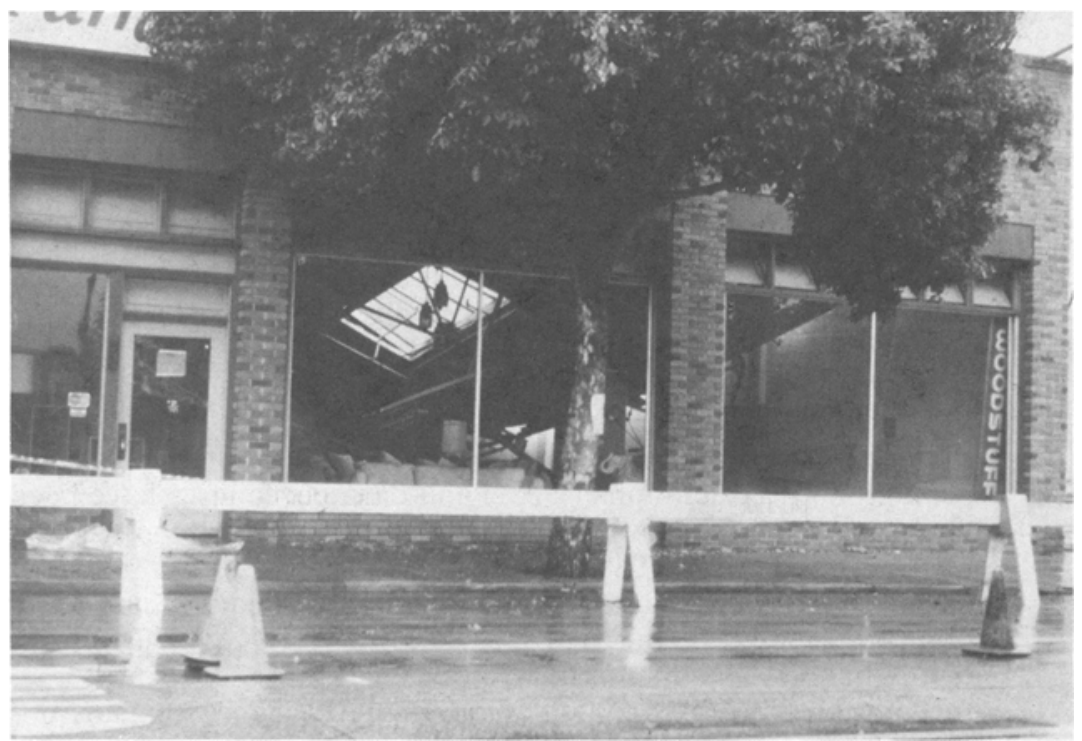

FIG. 1. Typical Failure due to Slip of Roof Joists off Their Wall Supports (Santa Cruz, Loma Prieta Earthquake) 
weak grout to fill an oversized rectangular cavity housing the supports for the beams.

In the absence of positive anchorage, the exterior walls behave as cantilevers over the total building height. The risk of wall out-of-plane failure due to excessive flexural stresses at the base of the wall obviously increases with its height, but, more importantly, global structural failure can occur by the slippage of the joists and beams from their supports (Fig. 1).

Although it is true that some nominal friction force exists at each support and may contribute to prevent failure at low dynamic excitation levels, the resistance thus provided is believed small and not considered during seismic hazards assessments.

\section{Anchor Failure}

When present in URM buildings, joists-to-walls anchors are of many different types, and their presence is often unrelated to seismic concerns. Thus, anchor failure is likely. While the metal of the anchor may fail, rupture may also occur at the connection points, i.e., the anchor could shear loose

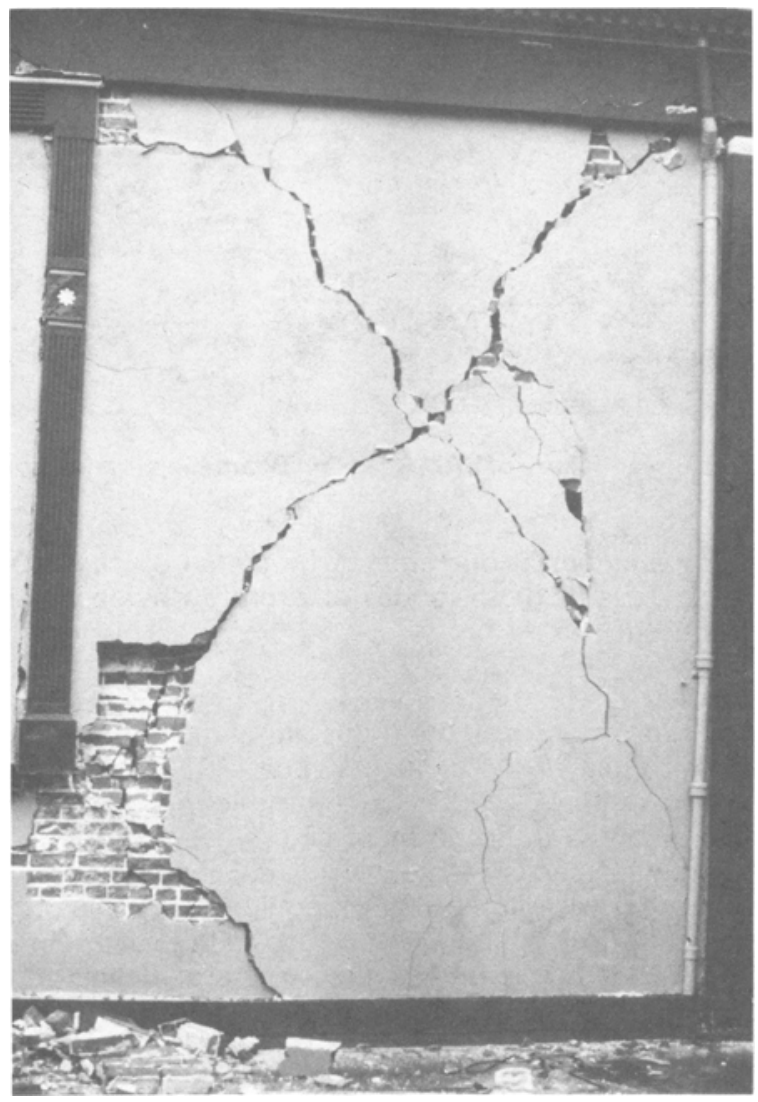

FIG. 2. In-Plane Shear Failure of URM Masonry Wall (Santa Cruz, Loma Prieta Earthquake) 


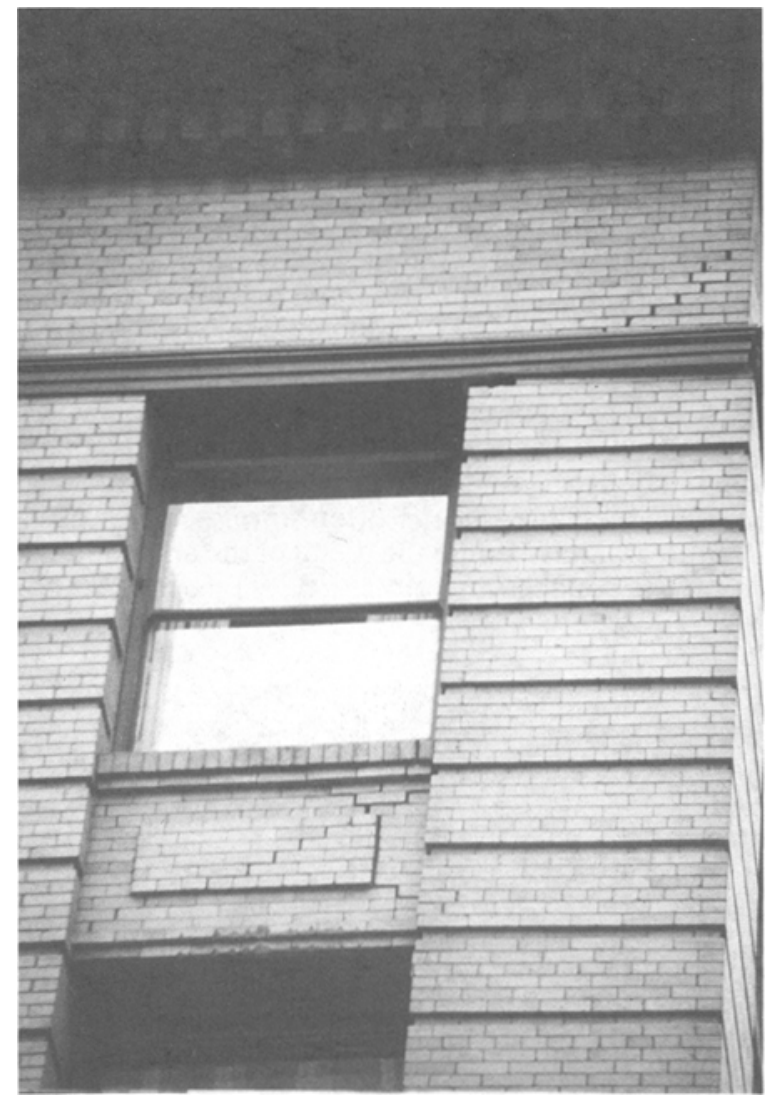

FIG. 3. In-Plane Shear Failure of URM Spandrel Beam (San Francisco, Loma Prieta Earthquake)

from the framing member at one end, or be pulled off the masonry at the other end. The details of these modes of rupture obviously vary with the type of anchors used.

\section{In-Plane Failures}

Excessive bending or shear may produce in-plane failures, depending on the aspect ratios of the URM elements. For URM walls, shear in-plane failures are more common, as expressed by double-diagonal (X) shear cracking (Fig. 2). Fortunately, until the shear cracks become unduly severe, the gravity-load carrying capacity of the walls is not jeopardized.

In masonry facades with numerous window openings, spandrels and the short piers between those spandrels may also fail in shear (Figs. 3 and 4). Usually the failure of one modifies the structural behavior significantly enough to preclude that of the other. Flexural failure of those structural elements is also possible, particularly for slender URM columns (Fig. 5); the resulting cracking at both ends of a URM element transforms it into a rigid body of no further lateral-load resisting capacity, unless gravity forces can provide a stabilizing effect. 


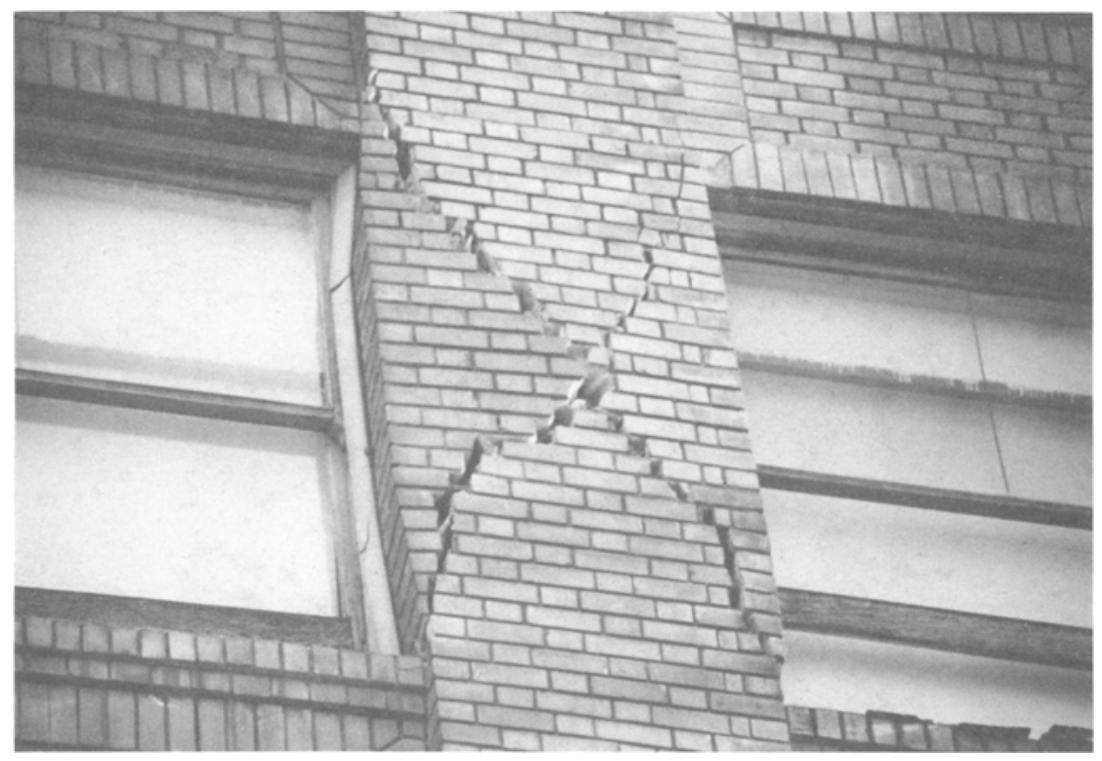

FIG. 4. In-Plane Shear Failure of URM Pier (Oakland, Loma Prieta Earthquake)

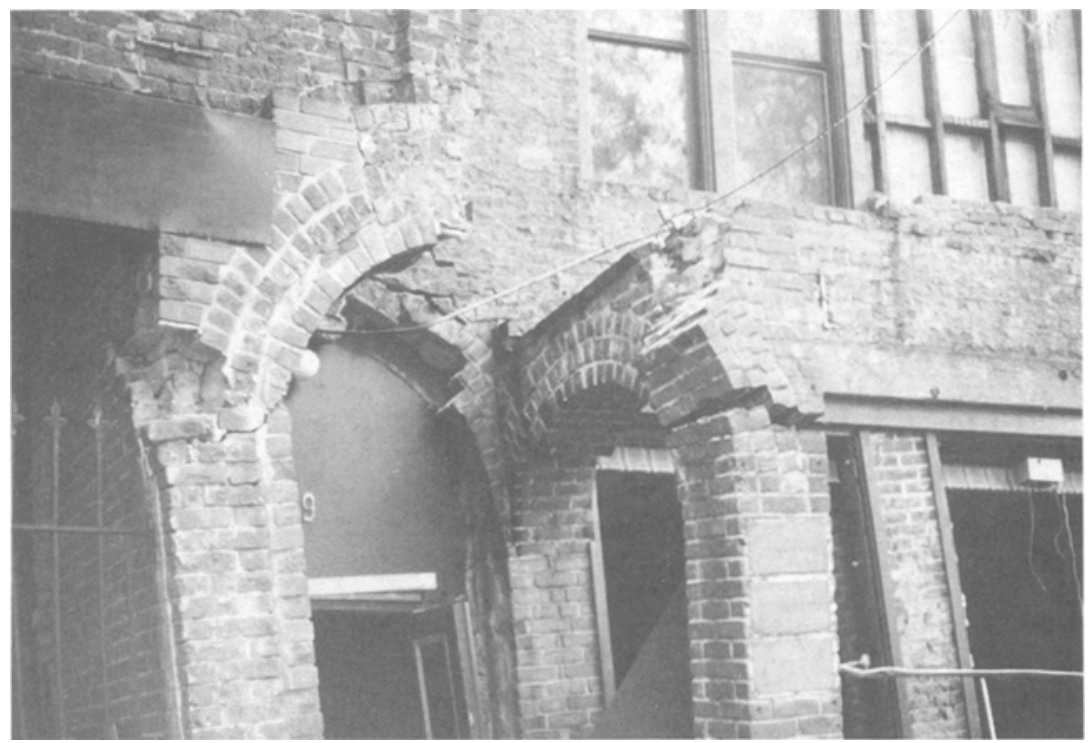

FIG. 5. Flexural Failure of Slender URM Column (Los Gatos, Loma Prieta Earthquake)

\section{Out-of-Plane Failures}

Joist-to-wall anchors provide out-of-plane support to the walls. If present in sufficient numbers and strength, these anchors will transform the out-of- 


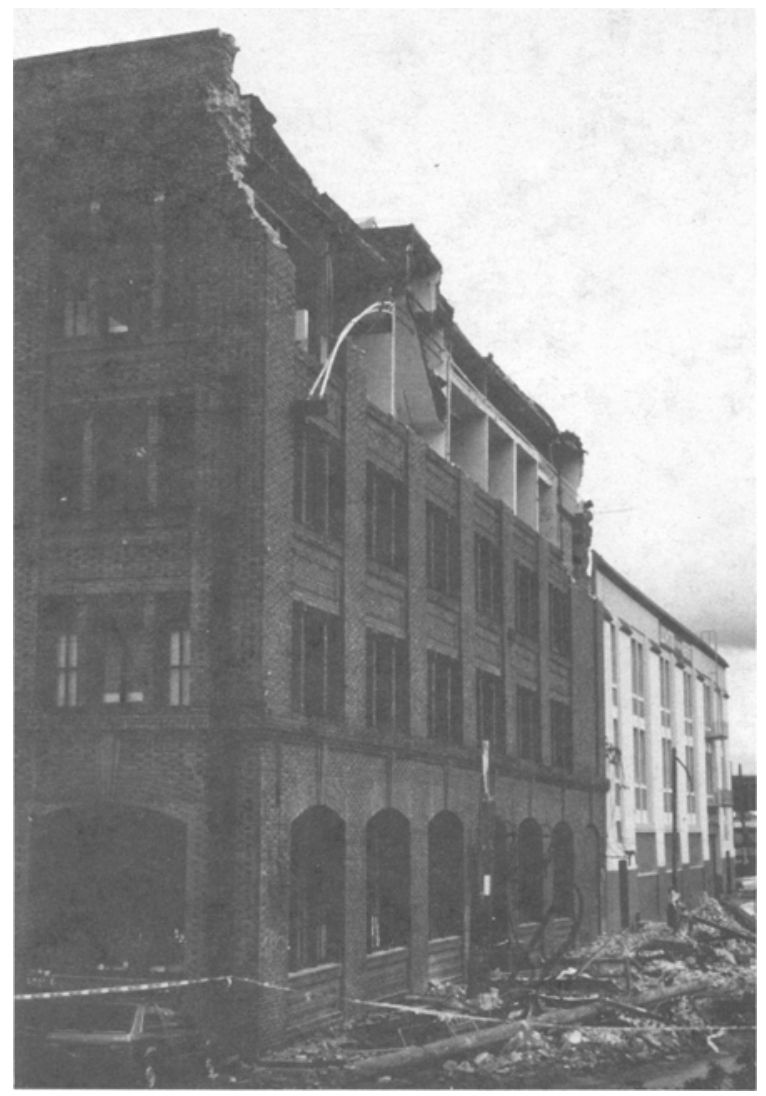

FIG. 6. Out-of-Plane Failure of UAM Top-Story Wall (San Francisco, Loma Prieta Earthquake)

plane behavior of the URM walls, from tall unrestrained cantilevers to shorter one-story-high panels dynamically excited at each end by the floor diaphragms. URM buildings are most vulnerable to flexural out-of-plane failure (Figs. 6 and 7). Furthermore, whereas an in-plane failure does not endanger the gravity-load-carrying capabilities of a wall, the unstable and explosive out-of-plane failure will.

Parapet failures fall in this category (Fig. 8). These nonstructural URM elements behave, if unrestrained, as cantilevers walls extending beyond the roof line; located at the top of buildings, they are subjected to the greatest amplification of the ground motions, and consequently prone to flexural failures. Gables of churches and other buildings, when improperly anchored to the roof, behave much like parapets (Fig. 9).

Multiwythe walls improperly bonded along their collar joint (e.g., no or discontinuous mortar) are also extremely vulnerable, each wythe behaving independently as an individual thin wall. The exterior layers without contact to any other structural components will usually fail first, at very low level of seismic excitation (Fig. 10). This is also true for URM veneers. 


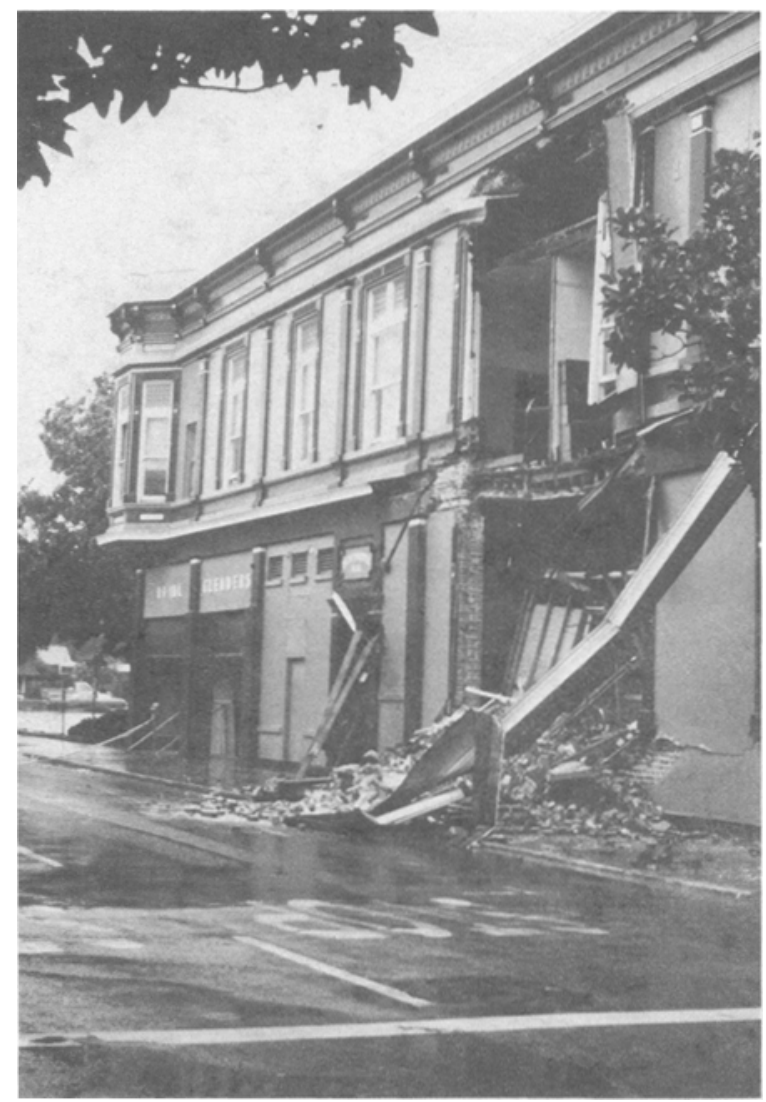

FIG. 7. Out-of-Plane Failure of URM Wall at Center of Building due to Excessive Diaphragm Flexibility (Santa Cruz, Loma Prieta Earthquake)

\section{Combined In-Plane and Out-of-Plane Effects}

Earthquake forces are bidirectional in nature, and thus each URM element is solicited in both its in-plane and out-of-plane direction. As in-plane shear cracking occurs, some triangular cantilever wedges are produced, whose out-of-plane strength is significantly weaker than that of the original uncracked wall panel. While these isolated portion of the wall are more susceptible to out-of-plane failure, the on-site identification of such a failure mode is nearly impossible, and such failures will generally be attributed uniquely and erroneously to the sole effect of out-of-plane forces.

Pounding against adjacent structures can also accelerate this combined failure mode. The recognition of pounding as a cause of severe damage is relatively recent. Old North American URM buildings built without separation are most vulnerable to this type of damage (Figs. 11 and 12).

\section{Diaphragm-Related Failures}

As indicated previously, properly anchored URM walls behave out-ofplane as one-story panels dynamically excited by the floor diaphragms at 


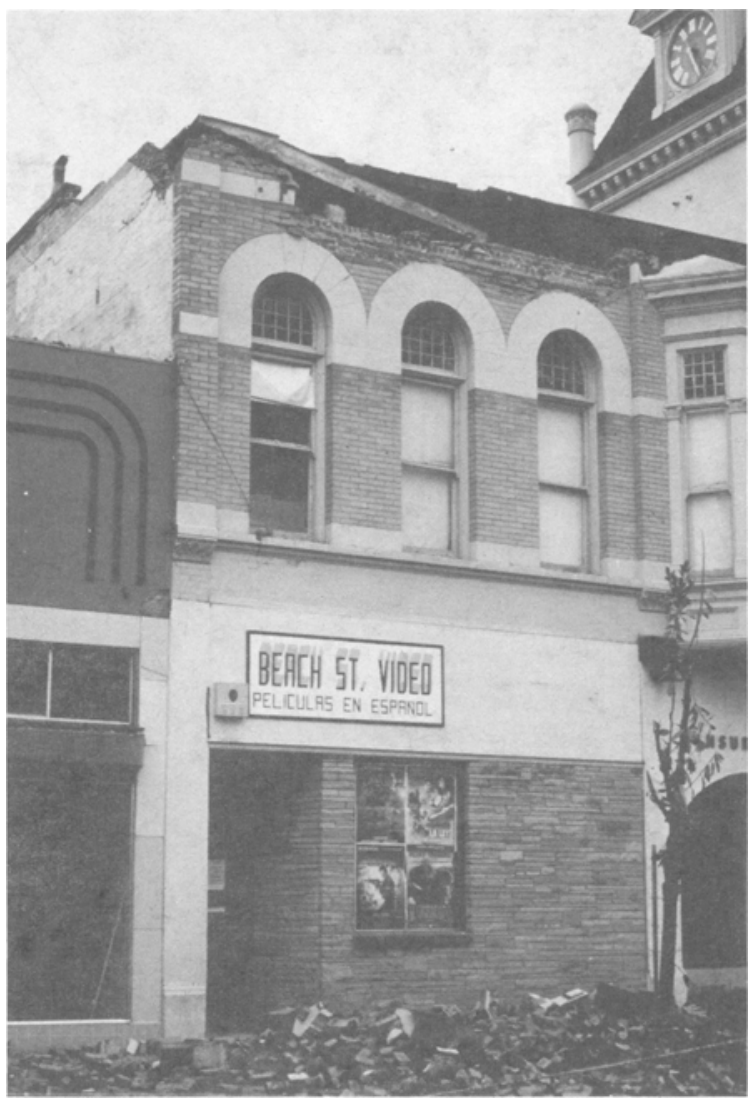

FIG. 8. Parapet Failure of 100 Front Street Building (Watsonville, Loma Prieta Earthquake)

their ends. Therefore, these diaphragms are dynamically solicited in-plane, and their flexibility has a considerable impact on the seismic response of URM walls.

The failure of the diaphragm itself is rarely observed following earthquakes. This could be attributable, partly, to the tendency of earthquake reconnaissance teams to mostly report observations made from the exterior of buildings. In most cases, damage to the diaphragm itself would not impair its gravity-load-carrying capacity. However, since flexible floor diaphragms behave as deep beams spanning between URM walls, the in-plane rotation of the diaphragm's ends can induce damage at the walls' corners. The absence of a good shear transfer between diaphragms and reaction walls also accounts for damage at the corners of walls, especially in long narrow buildings for which the diaphragm in-plane shear forces, due to bending in the long direction, cannot be transmitted over the small length of wall; the diaphragm will instead find its support by pushing on the URM walls in the transverse direction (Fig. 13). 


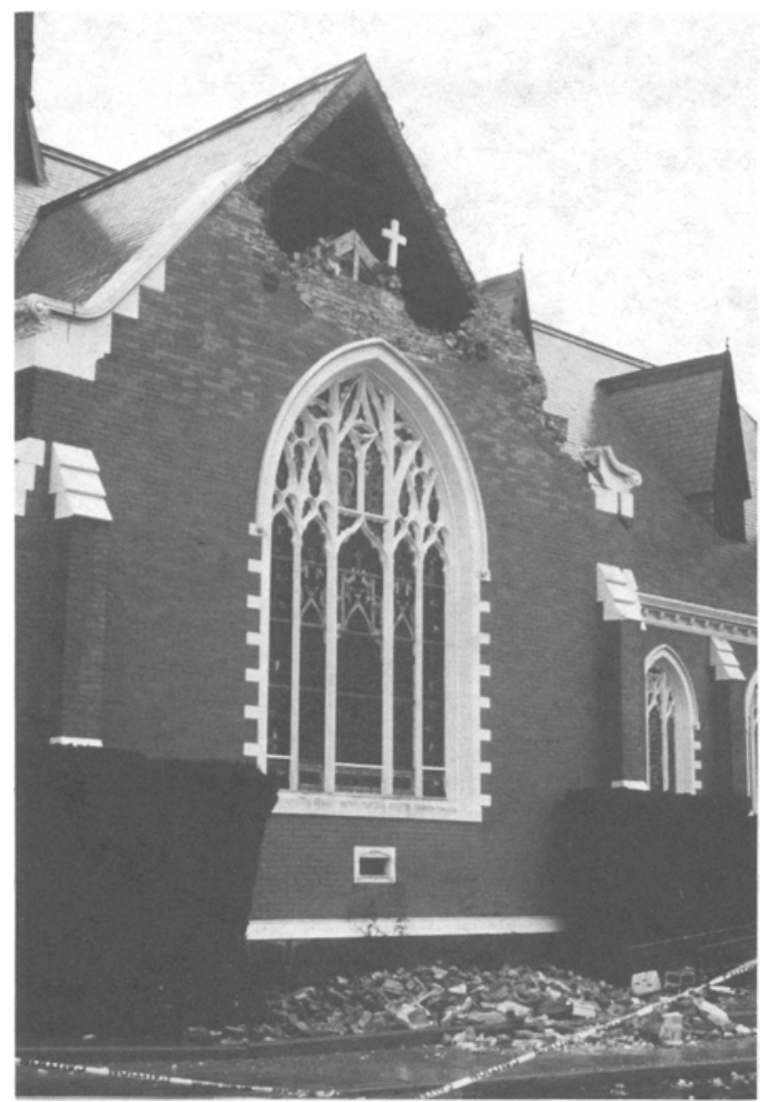

FIG. 9. Failure of Chruch Gable (Watsonville, Loma Prieta Earthquake)

\section{DESIGN CODE AND REQUIREMENTS FOR URM}

\section{Canadian Design Codes and Standards}

The current edition of the National Building Code of Canada (NBCC) (National 1990) requires buildings to be designed for a minimum lateral seismic base shear force, $V$, equal to

$V=\left(\frac{V_{e}}{R}\right) U \quad$ and $\quad V_{e}=v S I F W$

where $U=$ calibration factor to past practice and equal to $0.6 ; v=$ zonal velocity ratio related to the seismic risk at a given location; $S=$ perioddependent factor seismic response factor; $I=$ seismic importance factor; $F=$ foundation factor; and $W=$ dead weight of the structure. For masonry structures, still designed according to working stress methods, $66 \%$ of the value calculated by that equation would be used.

The NBCC prohibits the use of load bearing and lateral-load resisting unreinforced masonry in buildings located in regions where the PGA or PGV may exceed $0.08 \mathrm{~g}$ or $0.10 \mathrm{~m} / \mathrm{s}$, respectively. This effectively bans new 


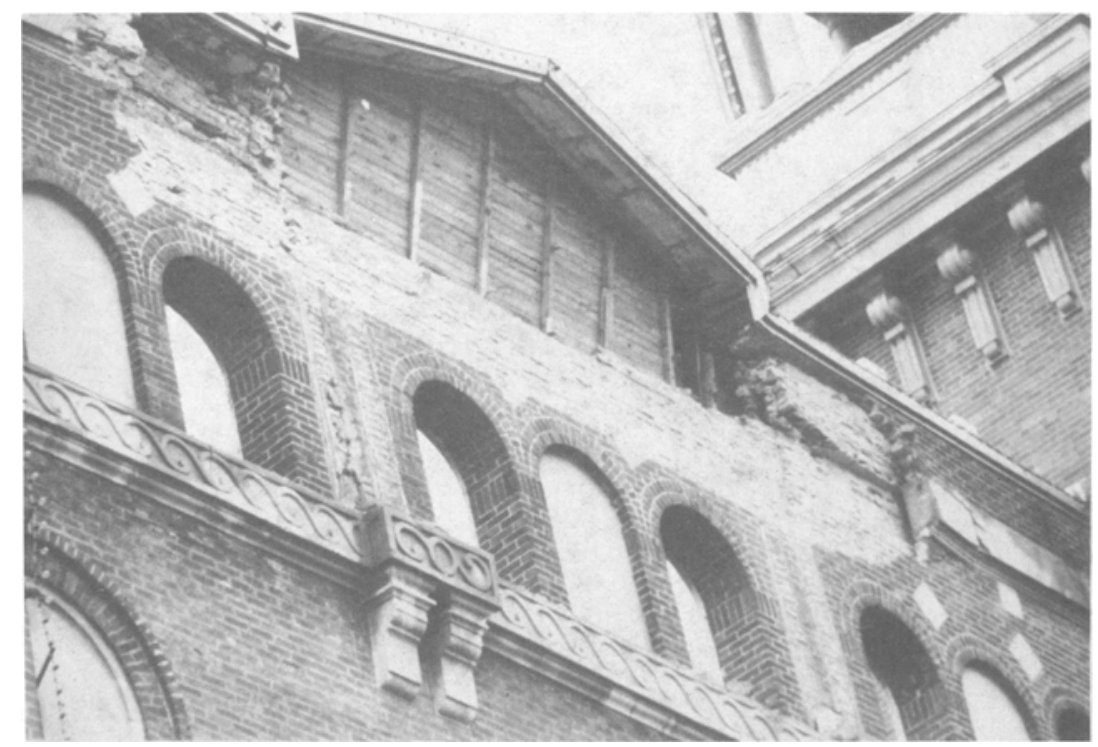

FIG. 10. Failure due to Combined out-of-Plane Failure of Parapet and Inadequacy of Collar Joint in Multiwythes URM Wall (Quebec City, Saguenay Earthquake)

URM buildings, and make noncompliant all buildings built prior to enactment of the code, in most Canadian cities.

In Canada, URM Buildings and their structural members shall also conform to CAN3-S304-M Masonry Design for Buildings (CAN 1984). This standard recognizes two possible design methods: (1) Empirical rules relying on assessments of compressive stresses and compliance with limits on wall slenderness ratios (which are proscribed for design against earthquake-induced forces); or (2) Engineering analysis based on simple elementary principles of elastic mechanics of materials coupled to some semiempirical relationships to account for stability and load-eccentricity effects. Essentially, the classical equations for shear stresses and combined axial and bending stresses are used (Gere and Timoshenko 1984)

$$
\begin{aligned}
& \left(\frac{M}{S}\right)+\left(\frac{P}{A}\right) \leq f_{m} \quad \ldots \\
& \left(\frac{M}{S}\right)-\left(\frac{P}{A}\right) \leq f_{t} \ldots \\
& \tau=\frac{V Q}{I t} \leq \nu_{o}+0.3 f_{c s}
\end{aligned}
$$

where $f_{m}, f_{t}$ and $v_{o}=$ specified allowable compression, tension, and shear stresses for masonry, respectively; and $f_{c s}=$ compressive stress due to dead load. For shear walls, a special provision also requires that $f_{t}$ be taken as zero. This straightforward and simple approach essentially reflects a conservative state-of-practice for the design of URM structures in Canada. The U.S. standards and practices differ little from the preceding. 


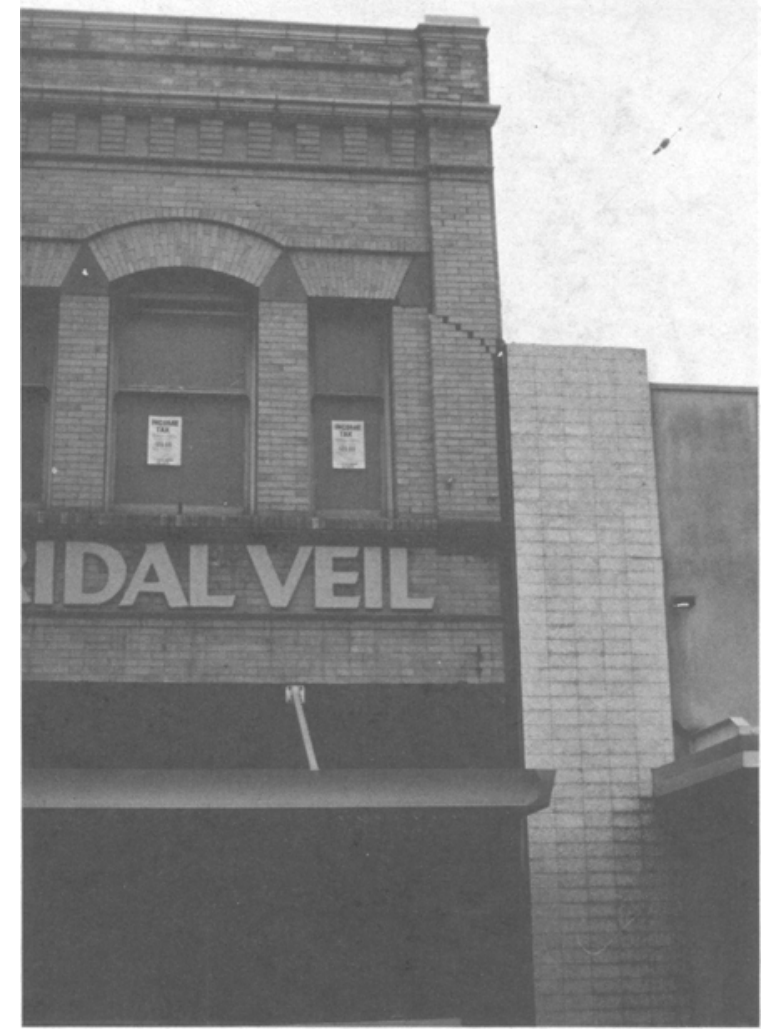

FIG. 11. Pounding-Induced Cracking (Watsonville, Loma Prieta Earthquake)

\section{U.S. Design Codes and Standards}

The American intricate structure of recommended and legally binding building codes precludes an exhaustive examination. However, for URM structures, the requirements of various codes are generally very similar; a review of three codes widely used in the U.S. appears adequate for the purpose of the current argumentation.

One particular material standard, the Building Code Requirements for Masonry Structures ACI 530-88/ASCE 5-88 (Building 1988), developed jointly by the American Concrete Institute (ACI) and ASCE, is popular in eastern North America. The earthquake static-equivalent lateral loads to use in conjunction with this standard must be obtained from the general building code locally used, or alternatively, from the ANSI A58.1-82 (Minimum 1982).

As before, two design methods of URM structures are suggested: one based on empirical rules, and another based on simple stress analysis, i.e., Chapters nine and six, respectively, of the ACI 530-88/ASCE 5-88 (Building 1988). (It is noteworthy that the latter, entitled "Design allowing tensile stresses in masonry," is considered generally applicable to URM, although 


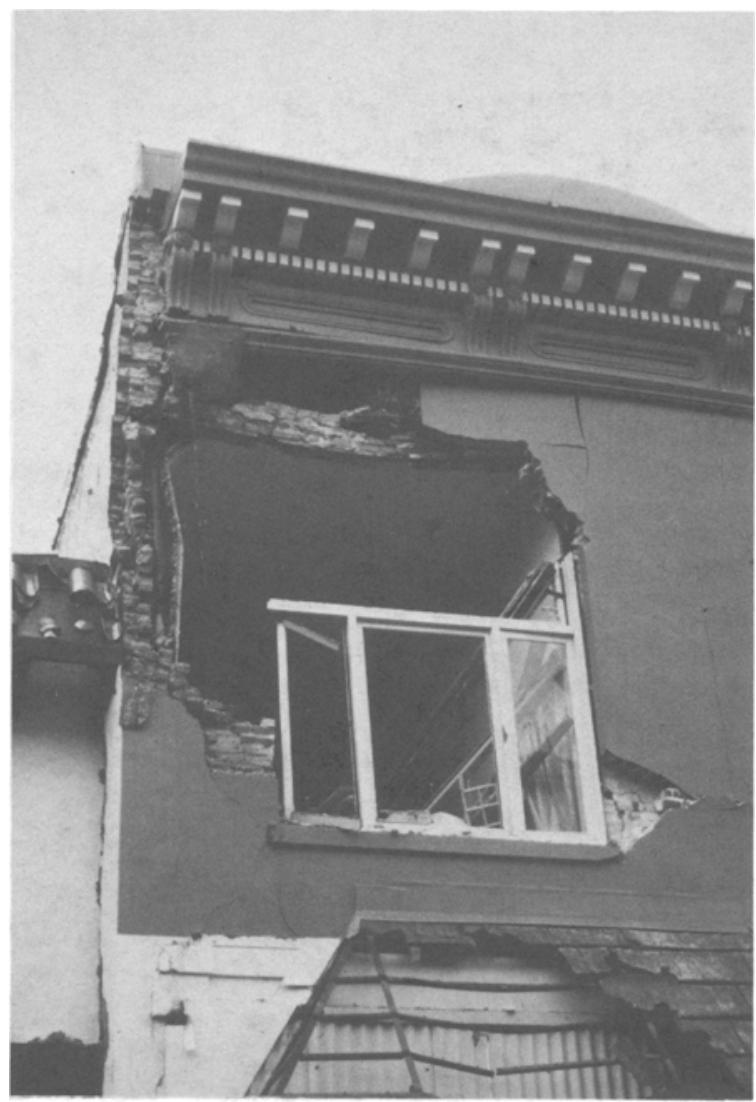

FIG. 12. Combined out-of-Plane/in-Plane/Pounding Failure (Santa Cruz, Loma Prieta Earthquake)

the term "unreinforced masonry" is, itself, nowhere mentioned in that standard.) The simple stress-analysis equations used for design, although of a slightly different format, are conceptually identical to those of (2).

The ACI 530-88/ASCE 5-88 (Building 1988) also: (1) Prohibits the use of the empirical design method for structures located in ANSI A58.1 seismic zones 3 and 4 or exceeding $10 \mathrm{~m}$ in height; (2) pays a special attention to multiwythe walls to ensure the adequacy of the collar joints or headers; (3) has a special section on seismic design for structures located in zones 2 or above, with provisions for the anchorage of walls to roofs and floors, and reinforcement requirements.

The NEHRP Recommended Provisions for the Development of Seismic Regulations for New Buildings (NEHRP 1988), which proposes itself as a model seismic code suitable for use throughout the U.S., endorses the ACI 530-88/ASCE 5-88 standard, with a few modifications; namely, to comply with NEHRP seismic zoning map and its limit states design format. Essentially, ANSI A58.1-82 seismic zones 0-4 are remapped into the NEHRP seismic performance categories $\mathrm{A}-\mathrm{E}$ (whose comprehensive description is 


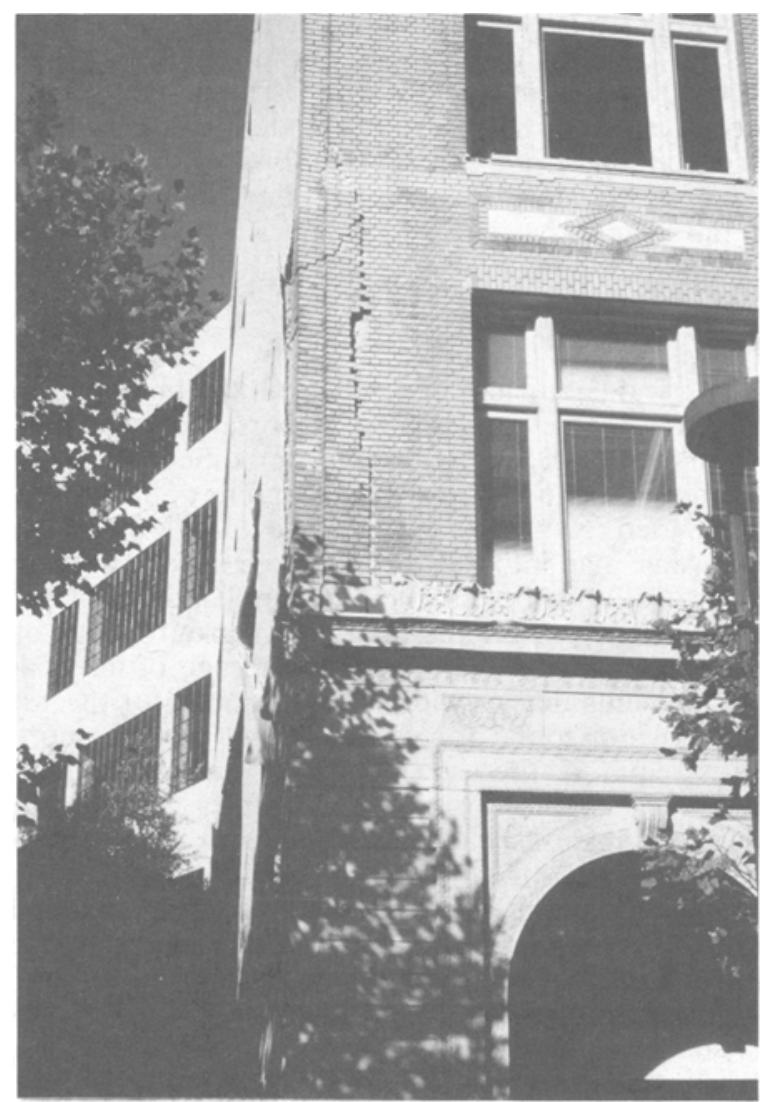

FIG. 13. Diaphragm-Induced Corner Damage to URM Pier (Oakland, Loma Prieta Earthquake)

beyond the current scope of work). NEHRP's minimum lateral seismic base shear force, $V$, is equal to, for stiff soils

$V=C_{S} W<2.5 \frac{A_{A}}{R}$

and

$C_{S}=1.2 \frac{A_{Y} S}{R T^{2 / 3}}$

where $A_{V}$ and $A_{A}=$ effective peak velocity-related (EPV) acceleration and effective peak acceleration (EPA), respectively, of the seismic risk at a given location; $S=$ soil coefficient; $R=$ response modification factor; $T=$ fundamental period of the building; and $W=$ dead weight of the structure. Peak ground velocities and EPA are roughly related by the relationship $\mathrm{EPV}=S_{V} / 2.5$, where $S_{V}$ is the spectral velocity, typically equal, in North America, to 2.3 times the peak ground velocity according to the 
Newmark and Hall (1982) elastic design spectrum, for a structure with 5\% damping. The allowable working stresses of the ACI 530-88/ASCE 5-88 are magnified by the NEHRP to comply with its limit state approach; this is somewhat deceptive given the nature of the design equations.

The Uniform Building Code (UBC) (Uniform 1991a) is used for seismic design in most of the western U.S. (Poland and Malley 1989). The UBC's minimum lateral seismic base shear force, $V$, is equal to

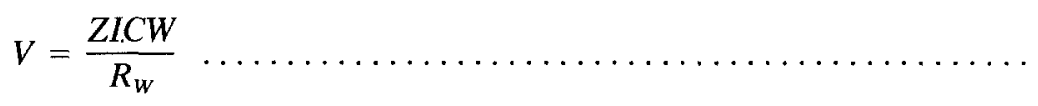

where $C=$ numerical coefficient dependant on the building's fundamental period and site soil characteristics; $I=$ importance factor; $W=$ seismic dead load of the structure; $R_{W}=$ response modification factor; and $Z=$ seismic zone factor linked to a seismic zone mapping of the U.S. Incidentally, it has been contended (Kariotis 1991) that the adoption of a more rational and objective seismic map into the UBC is much needed and long overdue.

Masonry structures must be designed in compliance to chapter 24 of the UBC. These provisions call for the bonding by grout or ties of all wythes in multiwythes walls and the mandatory anchorage of all walls to floors, roofs, or other elements that provide lateral support for the walls to resist and transfer design horizontal forces. In seismic zone 2 and above, wall reinforcement is required, the use of some mortars is prohibited, and, in zones 3 and $4,150 \%$ of the seismic design forces must be considered in designing shear walls against shear or diagonal tension failure. The empirical design method is restricted to buildings of $10 \mathrm{~m}$ or less in seismic zones 0 or 1, the equations for the design of URM as per the standard procedure are again conceptually identical to (2), and a design procedure for composite masonry construction (i.e. bonded wythes of different masonry types) is codified based on transformed section principles. Hence, the UBC is conceptually very similar to the other aforementioned codes and standards, but is somewhat more comprehensive and restrictive.

Finally, as Californian practice favors ductile structural systems, the Recommended Lateral Force Requirements and Commentary (1990) widely used in that state does not address URM construction.

\section{Uniform Code for Building Conservation}

Past evaluations of the seismic-resistance adequacy of existing URM buildings have generally revealed their noncompliance with the preceding design codes and standards. Failing the availability of alternative evaluation procedures, this verdict has often been misinterpreted as the urgent necessity to undertake comprehensive seismic retrofit works to remedy otherwise hazardous conditions. This approach fails to recognize the limitations in applicability of modern codes and their inappropriateness to deal with archaic materials and construction practices, and has led, in some instances already in eastern Canada, to the gutting of the entire interior URM structural systems of buildings and reconstruction using contemporary structural systems and materials on which the "preserved" historical facade was then attached. Such drastic measures and losses of the building heritage are not always justified; the excellent performance of some URM buildings that survived intact major earthquakes (Freeman 1932) testifies to this unrecognized strength of archaic structures.

The Uniform Code for Building Conservation (UCBC) (Uniform 1991b) is a code specifically designed to address problems germane to existing 
structures; it establishes acceptable life-safety requirements for buildings that undergo alteration or change in use, by offering alternative methods of acheiving safety so that the inventory of existing buildings can be preserved. The 1991 edition of the UCBC includes comprehensive seismic evaluation and strengthening provisions for unreinforced masonry bearing walls buildings (appendix chapter 1), and is rapidly gaining acceptance as a legal code for this purpose. A special procedure integrated into this document is essentially an adaptation of concepts first introduced by the ABK "Methodology for Mitigation of Seismic Hazards in Existing Unreinforced Masonry Buildings" (Methodology 1984); the evolution from this ABK work to the current $\mathrm{UCBC}$ and other parallel ordinances is well documented elsewhere (Draft 1990). The UCBC special procedure and methodology standardizes the steps of a structural engineering investigation of the seismicresistance adequacy of an existing URM building, and establishes strict guidelines against which this adequacy must be gauged. It includes: recommended procedures for the acquisition of building information, including the reconstruction of engineering documents (should originals be missing) and testing of components; a comprehensive review of anchorage of wall elements; an evaluation of the dynamic stability of anchored URM wall elements; a lower design lateral force level than for comparable new buildings; a detailed review of the adequacy of the diaphragms and URM walls, considering both out-of-plane and in plane motion; recommended structural elements and materials capacities; and a progressive abatement of the breadth of the seismic-mitigation effort for structures exposed to a lesser seismic risk, i.e., in zones of design effective peak ground accelerations (EPA) of $0.1 \mathrm{~g}$ and $0.2 \mathrm{~g}$, instead of $0.4 \mathrm{~g}$.

The elimination of the possibility of having URM walls separating from the roof and floors during an earthquake, with the ensuing collapse of the structure or parts thereof, is the cornerstone of the procedure. Thus, should the absence or inadequacy of existing ties between URM walls and diaphragms be discovered during the structural evaluation, the methodology automatically calls for a retrofit requiring at least the installation of a new wall anchorage system, including the bracing of parapets. Without this structural integrity, the methodology is not applicable. The special procedure is also limited to buildings with flexible diaphragms at all levels above the base of the structure, a maximum of six stories above the base of the building, and vertical elements of the lateral force-resisting system consisting predominantly of wall on at least two lines parallel to each axis of the building, although an open front on one side only is permissible. Although the UCBC is finding broad acceptance in parts of California where URM buildings of this architecture are common, the objective of this code is solely to mitigate the risk of life loss or injuries, although any improvements in life safety is invariably accompanied by some reduction in property damage. However, its indiscriminate application to heritage structures does not ensure a seismic performance meeting stringent preservation goals.

The UCBC/ABK methodology relies on some relatively new concepts describing the seismic behavior of URM buildings. It first assumes that the ground motion is directly transmitted unmodified to each floor by the end walls parallel to the direction of earthquake excitation. This is equivalent to saying that these walls are infinitely rigid in-plane. Thus, each floor diaphragm is seismically excited at its end-attachment points to the URM walls by the original unamplified ground motion. These diaphragms, in turn, push on the head walls, (i.e., the walls perpendicular to the ground-motion 
direction), which are excited in their out-of-plane direction. Therefore, the dynamic characteristic of the diaphragms directly influence the severity of the out-of-plane excitation of head walls and the required strength of wallsto-diaphragms anchors. The methodology imposes limits on diaphragms spans (as expressed by demand-capacity ratios) to control the severity of the diaphragm-amplified seismic excitations imparted to the URM head walls. Similarly, limits on slenderness ratios derived from dynamic stability concepts are also aimed at the protection of these head walls against outof-plane failure. Clearly, out-of-plane stability and structural integrity are the primary goals of this methodology.

As with other normal engineering procedures, when the existing conditions are found to violate the tolerable limits, the structure must be retrofitted by whatever strategy befitting to the structural engineer. However, for some particular deficiencies, the methodology explicitly mandates the nature of the corrective measures. For example, in high seismic-risk zones, if masonry piers provide bearing supports to steel beams, the methodology calls for the addition of steel columns next to the piers; these will act as shoring of the gravity system should the URM piers fail.

A detailed review of all aspects and steps of the methodology falls beyond the current scope of work, and the reader should refer to the UCBC/ABK documents and available Californian seminar notes (Earthquake 1981, 1983, 1986, 1986; Seminar 1991) if interested in the specifics of its application. At this time, thousands of URM buildings in California have been upgraded according to the preceding procedure (or variation thereof) and the seismic performance of some retrofitted buildings has already been reported (Moore et al. 1988; Deppe 1988; Rutherford and Chekene 1991).

The limitations of the methodology must be recognized. In particular, the simplifying assumption of rigid in-plane wall response, while acceptable for long lot-line dividing walls, may not be applicable for taller, more flexible buildings or for facades where, due to the presence of numerous opening, the lateral-load resistance is provided by numerous slender piers. Moreover, recent evidence (Tena-Colunga 1992) demonstrates that large amplification of the ground base acceleration are possible at the floor levels of even short, rigid buildings and should not be dismissed lightly; alternative rationalization of the UCBC assumption has since been proposed (Zsutty 1991). Also, given the dominant influence of the overburden on the dynamic stability of a wall, the decision to neglect the effect of the vertical ground motions, although rationalized in the $\mathrm{ABK}$ study that led to the $\mathrm{UCBC}$, has been challenged (Priestley 1985).

Another document, the ATC-22 (Handbook 1989; Seismic 1989), which evolved from the ATC-14 ("Evaluating" 1987; Poland and Malley 1989), proposes a methodology for evaluating the seismic resistance of existing buildings in a broader scope encompassing all types of engineered construction in a format compatible with the NEHRP design recommendations (NEHRP 1988). The section of the ATC-22 procedure that addresses the seismic evaluation of URM buildings is again largely based on the ABK methodology if flexible diaphragms and unreinforced masonry bearing and enclosure walls around the full perimeter exist (one open front is allowed). Failing this, and whenever judgement dictates (e.g. for irregular plan shapes), URM buildings must be treated by conventional procedures, as for other buildings.

As part of the ATC-14, a survey of the practice of consultants regarding seismic evaluation of existing structures was conducted. It revealed that 
most structural engineers use nonstandardized methods largely based on their own experience or office practice, and used existing methodologies only if required to by the clients. This was prior to the publication of the $\mathrm{UCBC}$, and it is unknown whether this practice has changed since.

\section{SUMMARY AND CONCLUSIONS}

The distinct concerns that pertain to the seismic performance of existing URM buildings have been presented. The various failure modes of URM buildings or components subjected to earthquake excitation have been described and, when possible, illustrated. A review of the state-of-practice as required by North American building design codes and standards has highlighted the rudimentary format of existing guidelines, and, thus, the low profile traditionally given to URM masonry as an engineering material. A special analytical procedure promoted by the UCBC and applicable to a certain class of URM buildings has been presented. The UCBC/ABK methodology (and parallel ordinances) is unique in North America in providing practicing engineers with a complete and readily applicable procedure for the seismic evaluation of existing URM buildings. Its wide application in the Los Angeles area also confers it a special status.

Reconnaissance teams visiting earthquake-stricken areas have reported on a very large number of damaged or failed URM buildings, and sometimes recognized that others nearby had remained intact. This reported performance of buildings was mostly confined to analysis by observation or sampling and testing of material properties; there are few published substantiated rationalization of why some URM buildings, which would be found severely seismically deficient as assessed by today's normal engineering procedures, have survived earthquakes of various intensities. Finally, alternate seismic rehabilitation philosophies are needed should intact preservation of heritage be the desired objective.

\section{ACKNOWLEDGMENTS}

This research program was partly funded by the Natural Sciences and Engineering Research Council of Canada. This support is sincerely appreciated.

\section{APPENDIX. REFERENCES}

Adham, S. A. (1985). "The Borah Peak, Idaho earthquake of October 28, $1983-$ buildings and schools." Earthquake Spectra, 2(1), 169-182.

Armenia earthquake reconnaissance report. (1989). Earthquake Engrg. Res. Inst., El Cerrito, Calif.

Bruneau, M. (1990). "Preliminary report of structural damage from the Loma Prieta (San Francisco) earthquake of 1989 and pertinence to Canadian structural engineering practice." Can. J. Civ. Engrg., 17(2), 198-208.

Building code requirements for masonry structures (ACI 530-88/ASCE 5-88). (1988). ASCE, New York, N.Y.

CAN3-S304-M84, Masonry Design for Buildings. Can. Standard Assoc., Rexdale, Ontario, Canada.

Cross, W., and Jones, N. P. (1991). "Historic buildings in the county of Santa Cruz and the Loma Prieta earthquake of 1989." Proc., 2nd Int. Conf. on Repairs and Maintenance of Historical Buildings, Computational Mechanics Publications, Southampton, U.K., 133-144.

Damage to unreinforced masonry buildings in the Loma Prieta earthquake of October 17, 1989. (1991). Calif. Seismic Safety Commission, Sacramento, Calif. 
Deppe, K. (1988). "Evaluation of strengthened and unstrengthened unreinforced masonry buildings in Los Angeles city." Earthquake Spectra, 4(1), 157-180.

DerKiureghian, A. (1990). "Observations from the Armenian earthquake of December 7, 1988." Proc., 4th U.S. Nat. Conf. on Earthquake Engineering, Earthquake Engrg. Res. Inst., El Cerrito, Calif.

Draft commentary to the structural engineers association of California and California building officials joint recommended unreinforced masonry building seismic safety provisions. (1990). California Seismic Safety Commission, Sacramento, Calif.

Earthquake hazard mitigation of unreinforced masonry buildings built prior to 1934. (1981). Struct. Engrg. Assoc. of California, Sacramento, Calif.

Earthquake hazard mitigation of unreinforced masonry buildings built prior to 1934update. (1983). Struct. Engrg. Assoc. of Calif., Sacramento, Calif.

Earthquake hazard mitigation of unreinforced pre-1933 masonry buildings. (1986). Struct. Engrg. Assoc. of California, Sacramento, Calif.

Elsesser, E., Naaseh, S., Walters, M., Sattary, V., and Whittaker, A. S. (1991). "Repair of five historic buildings damaged by the Loma Prieta earthquake." Proc. Seismic Historic Building Conf., Western Chapter, Assoc. for Preservation Technology, San Francisco, pp. 4-1, 4-39.

Esteva, L. (1988). "The Mexico earthquake of September 19, 1985-consequences, lessons, and impact on research and practice." Earthquake Spectra, 4(3), 413-426.

Evaluating the seismic resistance of existing buildings. (1987). Applied Technology Council Report ATC-14, Redwood City, CA.

Freeman, J. R. (1932). "Earthquake damage and earthquake insurance." McGraw Hill, New York, N.Y.

Gere, J. M., and Timoshenko, S. P. (1984). Mechanics of materials. Brooks/Cole Engrg. Div., Belmont, Calif.

A Handbook for Seismic Evaluation of Existing Buildings (Preliminary). (1989). Applied technology council report ATC-22, Appl. Technol. Council, Redwood City, Calif.

Hart, G. C., Kariotis, J., and Noland, J. L. (1988). "Masonry building performance survey." Earthquake Spectra, 4(1), 181-196.

Kariotis, J. (1984). "Survey of unreinforced masonry buildings." Reconnaissance report of the Coalinga, California, Earthquake of May 2, 1983, Earthquake Engrg. Res. Inst., Oakland, Calif., 145-156.

Kariotis, J., Krakower, M., and Roselund, N. (1991). The engineers' view-Loma Prieta: historic buildings, earthquake damage and seismic strengthening. California Preservation Found., Oakland, Calif.

Kariotis, J. (1991). "Preservation of historic buildings: coping with mandatory code compliance." Proc. Seismic Historic Building Conf., Western Chapter Assoc. for Preservation Technology, San Francisco, 12-1, 12-9.

Loma Prieta earthquake reconnaissance report: earthquake spectra, supplement to volume 6. (1990). Earthquake Engrg. Res. Inst., El Cerrito, Calif.

Meli, R. (1989). "Seismic behavior of masonry buildings." Lessons learned from the Mexico earthquake-Reducing earthquake hazards. Earthquake Eng. Res. Inst., Oakland, Calif., 181.

"Methodology for mitigation of seismic hazards in existing unreinforced buildings: The methodology." (1984). ABK-TR-08, Agbabian Assoc., El Segundo, CA.

Minimum design loads for buildings and other structures. (1982). Am. Nat. Standards Inst., New York, N.Y.

Mitchell, D., Tinawi, R., and Law, T. (1989). "The 1988 Saguenay earthquake-a site visit report." Geological Survey of Canada, Open File 1999.

Moore, T. A., Kobzeff, J. H., Diri, J., and Arnold, C. (1988). "The Whittier Narrows, California earthquake of October 1, 1987-preliminary evaluation of the performance of strengthened unreinforced masonry buildings." Earthquake Spectra, 4(1), 197-212.

Muria-Vila, D., and Meli, R. (1989). "Dynamic behavior of masonry structures." Lessons learned from the Mexico earthquake-Reducing earthquake hazards, Earthquake Eng. Res. Inst., El Cerrito, Calif., 188-191.

National Building Code of Canada, 1990. Nat. Res. Council of Canada, Ottawa, Ontario, Canada. 
NEHRP Recommended Provisions for the Development of Seismic Regulations for New Buildings-Part 1: Provisions. Build. Seismic Safety Council, Washington, D.C.

Newmark, N. M., and Hall, W. J. (1982). Earthquake spectra and design. Earthquake Engrg. Res. Inst., El Cerrito, Calif.

Poland, C. D., Malley, J. O. (1989). "Recommended modifications to ATC-14." Nat. center for earthquake engineering research, technical report NCEER-89-0012, State Univ. of New York at Buffalo, Buffalo, N.Y.

Priestley, M. J. N. (1985). "Seismic behaviour of unreinforced masonry walls." Bull. New Zealand Soc. for Earthquake Engrg., 18(2), 191-205.

Recommended lateral force requirements and commentary. (1990). Struct. Engrg. Assoc. of California, Sacramento, Calif.

Reitherman, R. (1985). "The Borah Peak, Idaho earthquake of October 28, 1983performance of unreinforced masonry buildings in Mackay, Idaho." Earthquake Spectra, 2(1), 205-224.

Reitherman, R., Cuzner, G. J., Zsutty, T. C., and Smith, G. W. (1984). "Performance of unreinforced masonry buildings." Reconnaissance report of the Coalinga, California earthquake of May 2, 1983, Earthquake Engrg. Res. Inst., El Cerrito, Calif., 113-144.

Scholl, R. E., and Stratta, J. L. (1984). "Reconnaissance Report on the May 2, 1983 Earthquake in Coalinga, California." Reconnaissance report of the Coalinga, California earthquake of May 2, 1983, Earthquake Engrg. Res. Inst., El Cerrito, Calif., $1-8$.

"Seismic Evaluation of Existing Buildings: Supporting Documentation." (1989). Applied technology council report ATC-22-1, Appl. Technol. Council, Redwood City, Calif.

Seminar on the new state wide earthquake hazard reduction code (1991 UCBC appendix chapter 1). Struct. Engrg. Assoc. of California, Sacramento, Calif.

Shah, H. C., Gere, J. M., Krawinkler, H., Rojahn, C., and Zsutty, T. C. (1984). "An overview of damage to the Coalinga commercial district." Reconnaissance report of the Coalinga, California, earthquake of May 2, 1983, Earthquake Engrg. Res. Inst., El Cerrito, Calif., 107-112.

Swan, S. W., Miller, D. D., and Yanev, P. I. (1985). "The Morgan Hill earthquake of April 24, 1984-effects on industrial facilities, buildings, and other facilities." Earthquake Spectra, 1(3), 457-567.

Tena-Colunga, A. (1992). "Seismic evaluation of unreinforced masonry structures with flexible diaphragms." Earthquake Spectra, 8(2), 305-318.

Uniform building code. (1991a). Int. Conf. of Build. Officials, Whittier, Calif.

Uniform code for building conservation. (1991b). Int. Conf. of Build. Officials, Whittier, Calif.

Zsutty, T. (1991). "Overview-ABK methodology." Seminar on the new state wide earthquake hazard reduction code (1991 UCBC appendix chapter 1), Struct. Engrg. Assoc. of California, Los Angeles, Calif. 